\title{
RELAÇÕES DE AÇÃO E AGÊNCIA EM WORLD OF WARCRAFT
}

\section{RELATIONSHIPS OF ACTION AND AGENCY IN WORLD OF WARCRAFT}

\author{
Thiago FALCÃO ${ }^{1}$
}

Resumo: A ação é o mais crucial elemento da experiência para com jogos eletrônicos. Não apenas a ação humana, mas mesmo o modo como partes do sistema interagem consigo. Considerando para além da fruição do indivíduo este aspecto material do meio, este artigo reflete a respeito da organização do tecido social em um Massive Multiplayer Online Role-playing Game (MMORPG). Observando, em especial, grupos voltados para a prática do raiding em World of Warcraft, questionamos que modo de existência pode ser encontrado neste contexto e, principalmente, de que forma este fornece uma chave de interpretação para as agências desta rede, ampliando, afinal, a teoria que discursa sobre este problema.

Palavras-chave: Agência, Jogos Eletrônicos, World of Warcraft, Teoria do Ator-Rede.

Abstract: Action is the most crucial element of videogame experience. Not only human action, but also how parts of a system interact with one another. Considering this material aspect of a medium, this paper reflects upon the organization of the social fabric in a MMORPG. By specifically regarding raiding groups in World of Warcraft, we question what mode of existence would offer the right key to interpret the agencies of this network, augmenting, therefore, the existent theory regarding this notion.

Keywords: Agency, Video games, World of Warcraft, Actor-Network Theory.

Thiago Falcão é Professor Adjunto do Curso de Jornalismo da Universidade Federal do Maranhão e Professor Visitante no Programa de Pós-Graduação em Comunicação da Universidade Anhembi Morumbi (UAM). É Doutor em Comunicação e Cultura Contemporâneas pela Universidade Federal da Bahia e coordena o Grupo de Pesquisa em Games da Sociedade Brasileira de Estudos Interdisciplinares da Comunicação - INTERCOM. E-mail: thfalcao@gmail.com. 
You're part of the game, You're cursed, you're damned

By now you understand. Blind Guardian, "Otherland".

\section{Introdução}

Menos de duas décadas nos separam do ano de 1997, o ano do Hamlet no Holodeck (MURRAY, 1997). Ainda assim, em se tratando de tecnologia e de meios de comunicação, é justo que se diga que este ano é longínquo - ancião, até - simplesmente pela transformação a qual experimentamos neste meio tempo. Sites de redes sociais, novas formas de ver televisão, paradigmas de aprendizado midiático e a ambígua cultura da convergência (JENKINS, 2006), são apenas alguns dos poucos exemplos que podem ser contemplados nas constelações de fenômenos da comunicação contemporânea.

Em se tratando de jogos eletrônicos, é possível verificar a mesma curva de desenvolvimento: a indústria, nesta última década e meia, evoluiu consideravelmente, em termos tecnológicos: resolução, processamento e jogabilidade, se considerarmos o lado material, sem dúvidas seriam as características que mais passaram por alterações. Mudanças profundas, todavia, também podem ser identificadas em outros campos relacionados aos video games, mais especificamente no modo como a prática se tornou comum - casual, para estar em consonância com desenvolvedores e esforços teóricos (JUUL, 2010) - com os jogos em sites de redes sociais e em dispositivos móveis, ensejando um movimento responsável tanto por modelos de jogabilidade quanto por modelos de negócio diferenciados.

O que nos leva a nossa primeira questão: como negar a importância da tecnologia - do aspecto material - no estudo de uma cultura como a dos jogos eletrônicos? Não é possível, responde Edwin Sayes (2014). "Se antes era possível afirmar com sinceridade que os não-humanos são as massas ausentes das ciências sociais, deve ser admitido que este não é mais o caso" (p. 134).

Naturalmente, o escopo da fala de Sayes não é restrito ao universo dos jogos eletrônicos. Ao contrário, seu argumento é estendido para as ciências sociais como um todo, como o próprio reforça, ao pontuar que "com a recente guinada material na teoria 


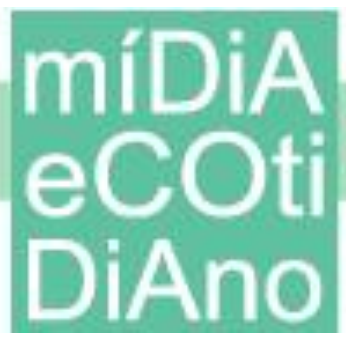

social (...) não se pode mais negar que as ciências sociais e as humanidades possuem um novo conjunto de objetos" (2014, p. 135).

Ainda assim, consideremos o estudo dos jogos eletrônicos: ainda nos primórdios Espen Aarseth e Janet Murray, dois dos mais celebrados teóricos do campo, lançavam as obras que, ainda hoje, são consideradas pedras fundamentais para os estudos dos jogos eletrônicos. Curiosamente, nem o Hamlet on the Holodeck, de Murray (1997), nem o Cybertext, de Aarseth (1997), possuem como objetos de estudo os jogos eletrônicos: ambos são tratados sobre a materialidade da experiência narrativa em novos meios de comunicação.

Para além da reafirmação da importância do aspecto material da experiência dos meios de comunicação, nos deparamos com um contexto no qual não-humanos, para adentrar a infralinguagem (LATOUR, 1988) da Teoria do Ator-Rede (LATOUR, 2005), permeiam praticamente todo o espectro, e a ação humana é executada quase que completamente através da dinâmica de delegação: um tipo de mediação através do qual as ações deslocadas abaixo - "para baixo, e não para fora [da rede]" (LATOUR, 1992, p. 40).

Em um MMORPG - em World of Warcraft (ou só Warcraft) - os não-humanos abundam. Seja em cada um dos desafios cuidadosamente posicionados para oferecer um nível ideal de dificuldade, seja nas interfaces com as quais deve o usuário lidar, seja nos elementos da narrativa que sugerem rumos de ação, um indivíduo raramente pode clamar autoria completa da ação - mas, em uma segunda questão, se mesmo em se tratando do corriqueiro dia-a-dia esta afirmativa é verdadeira, de acordo com reflexões latourianas, o que há de tão extraordinário no universo dos MMORPGs a ponto de torná-los dignos de análise?

A narratóloga Janet Murray oferece um motivo: "normalmente, não esperamos vivenciar a agência dentro de um ambiente narrativo" (MURRAY, 1997, p. 127) - não esperamos ser capazes de escolher entre os tantos caminhos que podemos tomar. $\mathrm{O}$ argumento de Murray (1997) é preciso, e tem sido utilizado como base para o entendimento da noção de agência quando relacionada aos jogos eletrônicos pelas últimas duas décadas, sofrendo, neste meio tempo, pouquíssimas críticas. Todavia, algo 


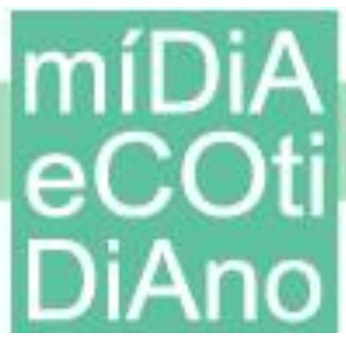

não deve deixar de ser considerado: o argumento serve a fins narratológicos, não contemplando o aspecto material dos jogos eletrônicos.

Naturalmente, ambos os aspectos - regras e ficção, para Juul (2005) - estão imbricados e são inseparáveis. A terceira questão, portanto, diz respeito à não existência de um aporte teórico que dê vazão a uma noção mais ampla da ideia de agência. A ação nos jogos eletrônicos só se dá mediante a interação com a narrativa? A resposta, como há de se esperar, é óbvia: existe um horizonte muito maior, não apenas de possibilidades de ação, mas, em especial, em termos de apropriação. A despeito de certamente existir a necessidade de uma teoria da agência com base na narrativa, se desejamos entender o escopo inteiro do fenômeno, precisamos dar vazão a um arcabouço que possa entendêlo completamente.

Daí, com o auxílio de uma decomposição do contexto em camadas de prescrição (FALCÃO, 2011), este artigo reflete sobre que actantes não-humanos possuem força agencial neste processo de formação do tecido social e, mais importante, qual seu papel. As considerações aqui feitas possuem como base a pesquisa empírica realizada durante os últimos seis anos, de 2008 a 2013, que atentou para diversas dinâmicas sociais contempladas no ambiente de Warcraft, entre elas, para o problema da agência em mundos virtuais. Neste esforço em particular, nos debruçamos sobre a prática de raiding, que consiste na formação e manutenção de grupos grandes com objetivos específicos e que precisam ser cuidadosamente geridos.

Dois pontos são epistemologicamente importantes neste desenvolvimento: o primeiro deles diz respeito ao fato de que dinâmicas prescritivas geram, por sua vez, dinâmicas discriminatórias (FALCÃO, 2011; LATOUR, 1992). Esta discriminação, é nossa hipótese, se torna não apenas base para que as estratégias de delegação se instaurem, mas possui papéis importantes: ela baliza as relações hierárquicas internas à rede, além de determinar também a amplitude da relação entre pesquisador e pesquisa.

O segundo ponto, para que sigamos com a argumentação do artigo, diz respeito ao fato de nos debruçarmos sobre os atores não-humanos. O fato de buscarmos, em especial, sublinhar o papel agencial da tecnologia não implica em uma posição desequilibrada com relação a atores humanos. Ela se estabelece à moda da subdivisão 


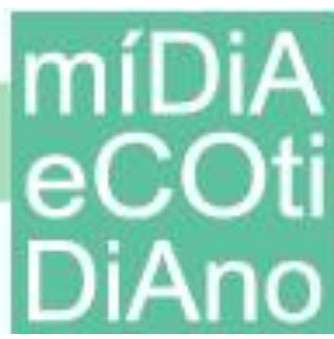

elaborada por Stalder (1997) entre as noções de sociograma e tecnograma, onde o primeiro diz respeito à construção de indivíduos dentro de uma rede, e o segundo, à construção de objetos, nesta mesma: “enquanto é útil, para propósitos de esclarecimento, separar estes dois níveis analiticamente, não é apropriado estudá-los separadamente porque eles estão altamente interconectados" (STALDER, 1997). Dito isto, finalmente sigamos à frente, retornando ao objeto para que nos aproximemos da prática e do modo como esta posiciona seus atores em uma rede.

\section{Warcraft: arena (interacional)}

World of Warcraft (Blizzard Entertainment, 2004) é um MMORPG: um tipo de mundo virtual que possui uma estrutura funcionalmente adaptada para criar situações de jogo, além de fomentar convívio social, uma dinâmica comumente experimentada através destes ambientes. Mundos virtuais descendem das MUDs - Multi-User Dungeons - da década de 1980, e consistem em ambientes nos quais pode-se navegar espacialmente com auxílio de uma representação - um avatar - e interagir com outros indivíduos conectados ao mesmo servidor. Um jogador, para adentrar o mundo, cria um personagem, escolhendo entre uma variedade de raças e classes - que orientam seu papel quando em grupo. Uma vez criado o personagem, cada interação específica com o mundo provê pontos de experiência responsáveis pela evolução em níveis ${ }^{2}$. Além do ambiente possuir uma vasta carta de características técnicas, ainda há de se considerar o fato de que este é o centro de uma cultura "voltada para os jogadores, e que oferece tudo, desde wikis a fan fiction, de modificações na interface a guias explicando como subir de nível, e mesmo como lucrar através da casa de leilões do jogo” (GLAS, 2012, p. 1).

Nos MMORPGs, a experiência narrativa clássica não segue a trajetória clássica do começo, meio e fim: ao invés disso, existe um sentido de passagem do tempo, no qual personagens, após derrotar um vilão em especial - geralmente parte de um arco narrativo maior - partem para encontros com maior nível de desafio. Isto confere a um

Mais informações acerca da estrutura e materialidade - níveis, organização de facções, raças, guildas, etc. - do jogo podem ser encontradas em Falcão (2010). 




jogo deste gênero um tempo de uso muito maior do que um jogo mais tradicional possui. Warcraft, por exemplo, está online há quase dez anos.

\section{Endgame: onde o jogo começa}

Objetivos, definitivamente, não faltam em Warcraft. O mundo virtual possui, segundo dados da própria Blizzard ${ }^{3}$, mais de seis milhões de palavras de conteúdo relativo às quests - tarefas mais triviais que dialogam para com a linha narrativa do jogo. Além disso, sua wiki ultrapassa a marca das cem mil páginas de conteúdo. Mesmo assim, a interação para com a linha narrativa não é a principal atividade desempenhada dentro do mundo virtual: para manter uma base que hoje ultrapassa os seis milhões de jogadores pagantes motivada, os mais diversos modelos de atividades são implementados: desde um complexo sistema de interação player vs. player $(P v P)$, passando por mini-games, como o sistema de pet battles, que relembra o clássico Pokémon (Nintendo, 1996-2013) até objetivos de pura vaidade, como a busca por montarias e animais de estimação diferentes, entre tantos outros.

Desta miríade de objetivos, um, em especial, é responsável por mover parte significativa dos milhões de jogadores, o endgame: cada expansão produzida para o MMORPG $^{4}$ conta com, além de um crescimento da área explorável e de novas características voltadas para a jogabilidade, um desenvolvimento na narrativa que dá suporte ao MMORPG. Esta característica, além da óbvia manutenção de objetivos, é responsável por transformar Warcraft em um meio de experimentação de uma narrativa em série. Alguns objetivos específicos só podem ser alcançados se o personagem se encontra em seu nível máximo - o que varia de acordo com a expansão sendo jogada. Este fator é responsável pelo dito, muito comum ingame, de que é quando se atinge o nível máximo que o jogo realmente começa.

Mesmo dentro de cada uma destas expansões, o conteúdo narrativo não é entregue de uma só vez. Cada uma demora, em média, dois anos para se desenrolar. No decorrer

\footnotetext{
3 Dados disponíveis em http://media.wow-europe.com/infographic/pt-br/world-of-warcraftinfographic.html.

4 São seis, ao total, agora em 2016; grosso modo uma expansão a cada dois anos, desde o lançamento do MMORPG.
} 


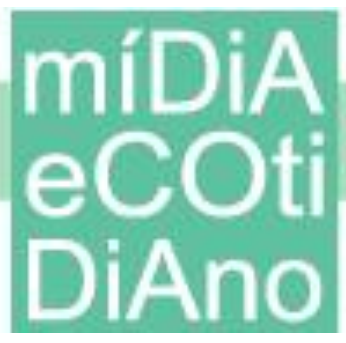

destes dois anos, detalhes do enredo são desenvolvidos, personagens evoluem, e se estabelece um sentido de continuidade: esta é uma das principais diferenças entre MMORPGs e jogos eletrônicos mais tradicionais, não existe suspensão temporal. Há uma série de especificidades a respeito de como o tempo narrativo é experimentado, e repercussões deste fator na experiência do meio, mas esta foge do desenvolvimento do presente esforço.

Dito isto, esta continuidade e este desenvolvimento narrativo são experimentados através das raids. As raids narram, por assim dizer, momentos importantes da história do mundo. Antagonistas poderosos aguardam heróis, dentro de castelos, cavernas ou a céu aberto, para que estes, ao experimentar o único desfecho possível à narrativa de Warcraft, derrotem-nos e dividam, então, os espólios do combate - na maioria absoluta das vezes armas e armaduras que aumentam as capacidades latentes de um personagem, permitindo que ele avance a batalhas com um maior nível de dificuldade. Um último ponto operacional que vale a pena ser mencionado diz respeito ao fato de que estes espólios possuem oferta limitada, criando uma economia da prática.

A entrada para uma raid é posicionada geograficamente no mundo, através de um portal. Ao atravessar este, os jogadores são transportados para uma instância da localização, o que significa que pode-se ter várias instâncias ativas ao mesmo tempo. Na prática, este recurso é utilizado para dar vazão a milhares de jogadores que engajam na prática de raiding.

Finalmente, sobre a prática, é possível que, dada a explicação relativamente simples, o leitor desenvolva a impressão de que, das atividades em Warcraft, as raids são das mais triviais. Ledo engano. Para que seja possível derrotar um inimigo como este - geralmente uma raid possui vários, engajados de forma ordinal, e organizados por nível de dificuldade crescente - é necessário que jogadores se organizem em grupos, que podem variar entre 10 e 25 componentes e, repetidamente, tentem desenvolver a série de ações que vai ser responsável pelo triunfo na batalha.

Boss battles, como são chamadas estas batalhas, são extremamente meticulosas. Jogadores se organizam em uma complexa coreografia que vai, aos poucos, e ao mesmo tempo, satisfazendo dezenas de condições - desde as condições de vida de um 


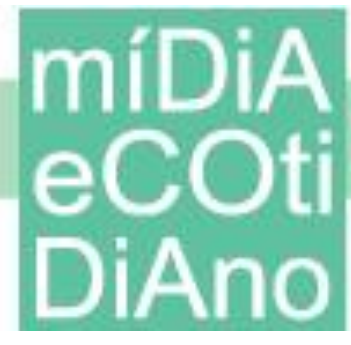

personagem, medidas por pontos de vida (health), passando pela capacidade de um personagem de produzir magias, medida por pontos de mana (mana), até chegarmos em requisitos arbitrários, como um limite de tempo, no qual o boss passa para um estado de rage e encerra a sessão, decretando a derrota do grupo.

A dinâmica que se instala, portanto, é a de repetição. Semana após semana as raids são reiniciadas, e seus bosses voltam à vida, para serem, novamente, derrotados. Esta dinâmica não só é responsável por garantir uma longa vida útil a cada uma dessas ilhas de conteúdo, mas, principalmente, garantir que na próxima atualização todo o grupo esteja equipado o suficiente para continuar seu pleito.

$\mathrm{O}$ artigo definido defronte à palavra grupo revela o rumo que toma esta argumentação. Raids não são uma atividade trivial, como dito, e naturalmente, não podem ser adentradas arbitrariamente. No contexto do MMORPG grupos voltados especificamente para esta prática se formam, e no entendimento do modo através do qual a rede composta por jogo e jogadores capacita não apenas a formação mas a existência de uma trajetória para estes se encerram as nuances do entendimento de uma prática relativamente negligenciada pelo corpo acadêmico voltado para os game studies.

O grupo depende de um híbrido, contudo - é um híbrido, afinal. Considerando a dificuldade que alguns setores da academia possuem em conseguir visualizar a hibridização e a ação técnica, nos aproximemos da dinâmica acima descrita. Por um momento, é necessário que, para entender o contexto descrito, nos debrucemos sobre a ferramenta, sobre a tecnologia. Considerar a existência dessa materialidade como atributo definidor da formação social que ali ocorre nos permite, portanto, fazer algumas considerações a seu respeito.

Antes, uma medida caucionária: sim, a materialidade, o aspecto técnico, operacional, são atributos definidores da experiência. Não mais ou menos, contudo, que seu conteúdo: interações, símbolos, indivíduos. "Todas as relações deveriam ser vistas como tanto social quanto técnicas”, nos alertam Law e Bijker (1992, p. 290). Que ainda se precise professar algo como tal é culpa do fantasma do determinismo tecnicista que ainda ronda o pensamento acerca da tecnologia. Ponto é que sim, existe uma nota de determinismo quando a tecnologia em evidência são os jogos eletrônicos: não porque 


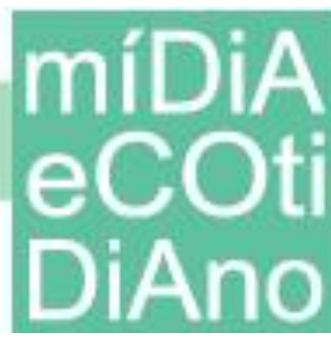

seu conteúdo incite algo, tal qual modelos comunicacionais de meados da década de 1920, mas porque para que se possa fruir um jogo adequadamente, suas premissas precisam, antes de tudo, ser satisfeitas.

Aqui nos remetemos, finalmente, à ideia de prescrição (LATOUR, 1992; AKRICH, 1992) - ou, mais precisamente, sua organização em camadas. Como foi pontuado anteriormente (FALCÃO, 2011), prescrição é uma característica através da qual os atores podem 'ensinar' para o contexto de que forma devem ser aproximados. Considerando a amplitude da Teoria do Ator-Rede, estas contemplam toda dinâmica relacional, como descrito em minúcias por Latour (1992). Sua organização em camadas diz respeito ao fato de que a tecnologia vai encapsulando em si módulos que são responsáveis por parcelas específicas da ação posicionada na rede. Módulos que quando expandidos demonstram toda uma ecologia dentro de si, mas que funcionam de forma opaca, com entradas e saídas pré-determinadas, e que por isso são, de certa forma, esquecidos: caixas-pretas (LATOUR, 1992) - "[u]m processo que transforma a produção conjunta de atores e artefatos em algo inteiramente opaco" (LATOUR, 1992, p. 36).

Ao observar mais cuidadosamente estas caixas-pretas, podemos entender de que forma elas se relacionam entre si - o que elas prescrevem umas para as outras. É importante, ainda, conceber que uma camada não precisa ser apenas composta pela por não-humanos. Lembremo-nos, toda relação é sócio-técnica, o que significa que podemos identificar indivíduos e tecnologia - humanos e não-humanos - em qualquer uma dessas camadas.

Mas, qual o intuito da decomposição, afinal, se as caixas pretas agem de forma opaca - se, ao interagir com o nível superior de uma caixa preta, perdemos a noção de tudo que está, ali, encerrado? A resposta está em uma particularidade dos jogos eletrônicos: sua natureza híbrida é responsável por uma organização do fenômeno, no que diz respeito ao meio, que faz o faz diferir com veemência de outras formas de experimentação de narrativas: um jogo eletrônico é, afinal, um jogo, como sugeriu Gonzalo Frasca há muito (FRASCA, 1999), incauto da repercussão que esta aparentemente inócua sentença teria, no campo. 


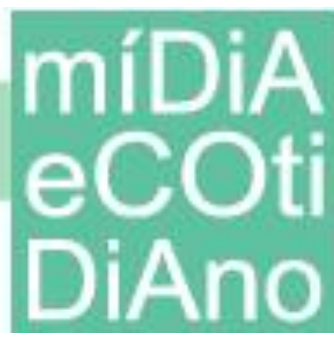

Diferentemente do que acontece em outros contextos que concernem à relação entre humanos e não-humanos, o fechamento das camadas de prescrição, ou seja, das caixas-pretas às quais se relacionam aspectos distintos do MMORPG, não garante a opacidade dos sistemas a elas internos. Em outras palavras, ainda que certos construtos sejam necessariamente internos a outros - a narrativa do mundo só pode ser experimentada através de sua interface - a atenção pode ser chaveada, e a interação pode ser levada de forma direta a uma camada que possui componentes prescritivos inteiramente seus. Por ora, é o suficiente que estabeleçamos esta postulação: camadas de prescrição mantêm sua potência interacional sendo, por sua vez, chaveadas conforme a situação. Havemos, ainda, de retornar a este ponto, mas sigamos à frente com as nuances do conceito de prescrição.

O cerne da questão principal deste artigo se localiza em uma característica associada ao conceito de prescrição: a ideia de discriminação. Toda prescrição, para Latour (1992), é seguida de discriminação. Se um objeto técnico possui um script - um enquadramento da ação, definido na convergência entre atores humanos, não-humanos e o espaço no qual estes se encontram, "tal qual o script de um filme", para Akrich (1992, p. 208) - ele prescreve um tipo de ação específica para aqueles que com ele interagem. Canetas, tesouras e britadeiras possuem scripts que não apenas ensinam como se dá seu uso, mas, ao mesmo tempo, restringem quem pode usá-los.

Naturalmente, há um caráter processual na aproximação entre actantes. Consideremos as fases, por exemplo, de aprendizado de atividades que, em nossa vida adulta, tornam-se triviais: o uso de talheres, o emprego de um abridor de latas, andar de bicicleta, dirigir. À medida que a convergência entre humano e não-humano se dá, em uma situação como esta, a discriminação é esperada.

Eventualmente, contudo, há de se atingir um contexto em que a mediação entre humano e não-humano é tão harmônica que a atividade desaparece. Não porque abdiquemos do aspecto técnico, mas simplesmente porque seu uso torna-se invisível: ao escrever uma carta, dificilmente paramos para apreciar como a caneta esferográfica desliza sobre o papel, ela se torna uma extensão do pensamento - não, ela o é. Recordemo-nos que, quando alunos do ensino fundamental nos era proibido o uso de tal 


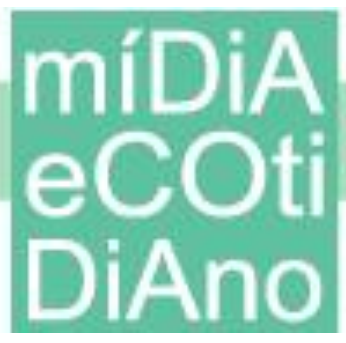

objeto - mas por quê? Podíamos, infantes, borrar o papel, sujando-o ou errar a grafia de uma palavra, sem que pudéssemos consertá-la.

Talvez, para Latour (1992), a discriminação não passe de um efeito colateral das características prescritivas - um dentre os tantos obstáculos que se interpõem à subsistência de uma rede. Ainda assim, quando nos movemos da teoria de escopo mais genérico para um domínio específico, como é o dos jogos eletrônicos, é impossível deixar de perceber o modo pelo qual esta característica é importante para a formação do tecido social. Retornemos a este contexto para entender de que forma isto se dá.

\section{Mas... Quem é o melhor jogador?}

Consideremos um jogo qualquer. Um jogo, perceba-se - um construto que obedeça as premissas descritas por Juul (2005, p. 32-33) no Half-Real: a presença de regras, de um resultado quantificável variado, a valorização do resultado, o esforço do jogador, a ligação do jogador ao resultado e, finalmente, a existência de conseqüências negociáveis. A despeito do modelo de Juul (2005) ser fonte de um grande número de discussões, escolhemos simplesmente tomá-lo como ponto de partida para a organização, sem necessariamente questioná-lo.

Tomemos como exemplo Super Hexagon (Terry Cavanagh, 2012). Hexagon ${ }^{5}$ é um jogo multi-plataforma que possui uma premissa extremamente simples: o cursor central, representação do jogador no ambiente, não pode tocar as paredes que se fecham. A partir daí, podemos derivar duas outras premissas que são as únicas no jogo: à medida que o tempo passa, a velocidade das paredes aumenta; e o movimento do cursor se dá nos sentidos horário e anti-horário, em torno do centro da tela.

As regras de Hexagon podem ser descritas em poucas linhas: este é, sem dúvidas, um jogo simples. Mais que Warcraft, certamente. Dentre as muitas diferenças entre um e outro - uma comparação aparentemente esdrúxula - observemos uma, em específico: Hexagon é tão simples que sua jogabilidade não dá vazão a grandes dinâmicas de apropriação. Não discutimos aqui a apropriação externa, pelo contexto cultural - o fato de o jogo ser usado em um episódio do cartoon Adventure Time (Cartoon Network,

\footnotetext{
5 Detalhes sobre o jogo em http://superhexagon.com.
} 


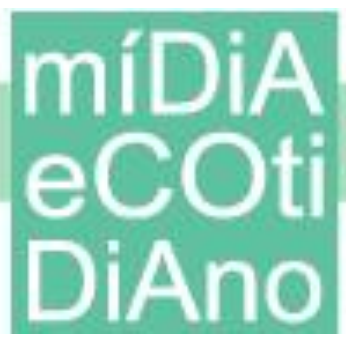

2010) por exemplo. O que está em jogo são estratégias de apropriação interna, como as que estão disponíveis em jogos como o próprio Warcraft. Em Hexagon, só há um objetivo: ir o mais longe possível.

Ao jogar Hexagon, se estabelece um vínculo entre jogo e jogador, no qual o jogo provê desafios e o jogador possui formas limitadas de como resolvê-los. A ação, retornando, é parte essencial do jogo e escolhas são relevantes para o desenrolar da atividade. Consideremos este vínculo um contrato, à moda dos contratos de leitura celebrados pelos analistas de discurso: ao adentrar o ambiente específico, o jogador se conforma às limitações, e suas ações passam a ser agenciadas pela materialidade do jogo. Se o argumento, aqui, parece determinista, é porque ele o é. No momento em que um indivíduo escolhe entrar em jogo, ele há de agir de acordo com as regras deste ${ }^{6}$.

Adentrando esta relação entre materialidade e agência é que se encontra a dinâmica da discriminação. Jogos são atividades necessariamente agônicas: a discriminação, neles, não é simplesmente uma questão passageira ou trivial, ela é o que faz diferir um jogador do outro, qualitativamente. Esta lógica se aplica tanto a esportes quanto a jogos de raciocínio -contemplando, naturalmente, os jogos eletrônicos. Se podemos resumir a problemática em uma frase, o jogador que menos sofre os efeitos da discriminação está mais bem equipado para o jogo. Isto significa que tal dinâmica é particular aos jogos? Não, em nenhum momento. O que torna o argumento aqui particular é o fato de que em jogos especialmente competitivos, a discriminação é um poderoso vetor de formação do tecido social.

Se considerarmos a dinâmica dos raid groups, em especial atentando para sua profissionalização (TAYLOR, 2012), é facilmente perceptível que o jogador que consegue extrair mais de seu personagem, que domina de forma mais precisa os aspectos técnicos do jogo, que busca a fronteira entre o que é permitido e o que é apropriado, é o jogador que sofre menos discriminação. O domínio do aspecto técnico não é, contudo, um status que surge ex nihilo. Taylor (2012, p. XX) bem pontua que este

Existe outra faceta desta problemática que diz respeito à necessidade da encenação do jogo para que este exista. Lembremo-nos, de que a "essência é a existência, e a existência é a ação" (LATOUR, 1992, p. XX) - mas, por ora, esta faceta há de ser negligenciada em detrimento da argumentação que há de se seguir. 


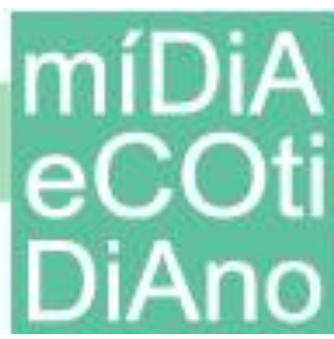

domínio é fortemente dependente "da socialização ativa em uma identidade profissional por toda uma miríade de atores e forças”. Esta afirmação, além de condizer com o entendimento em rede e de corroborar o caráter processual da aproximação a qualquer objeto técnico ainda aponta para o objetivo ulterior do artigo, o discurso acerca de um modo de existência organizacional em grupos de jogadores - guildas - orientados para a prática de raiding.

\section{Uma Noite Qualquer em Warcraft}

Até então, a descrição estrutural foi responsável por um entendimento desconectado do objeto - nosso intuito, a partir de agora, é, finalmente, dar vazão à voz dos atores, organizando-os e descrevendo seus feitos de forma que, uma vez finda a descrição, possuamos um entendimento adequado das dinâmicas internas a Warcraft e sua cultura. Especificamente, a parcela que compõe o relato presente neste artigo é apenas uma fração do contexto social experimentado quando dos seis anos de pesquisa / fruição. Ela, contudo, se apresenta de forma significativa para a problemática aqui trabalhada.

Em novembro de 2011, durante a expansão Cataclysm, a Blizzard abriu a público a raid Dragon Soul. Esta encenava a história da última investida das raças de Azeroth um dos mundos nos quais se dão os eventos do universo de Warcraft - contra Deathwing, grande vilão da expansão. É válido pontuar, apenas para ressaltar o aspecto de serialidade do MMORPG, que em cada expansão figura um grande antagonista, e que este geralmente é o último boss a ser derrotado em uma raid, um ou dois anos após o lançamento da expansão.

A pesquisa vinha sendo conduzida, então, na guilda Vipers, do servidor brasileiro Azralon - e já se encontrava em seu último estágio. Antes da Vipers, a pesquisa me levara por outras quatro guildas em três diferentes servidores, cada uma delas, cada um deles, com suas devidas orientações, práticas e idiossincrasias. Na Vipers, contudo, havia algo que estava ausente nas experiências anteriores: a despeito de a guilda não se 


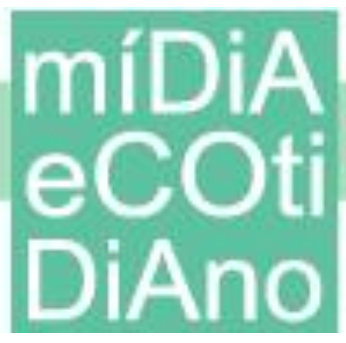

considerar hardcore ${ }^{7}$, a performance de cada jogador era muito levada a sério. Como foi antes mencionado, este tipo de organização, voltado para a composição de um grupo através de sua desenvoltura para com requisitos técnicos, é um caso simples de como a discriminação age enquanto vetor de formação do tecido social.

Acerca da Vipers, há de se mencionar que a guilda era um reduto de amigos que passaram a jogar juntos. Isto significa que o grupo possuía uma identidade prévia, proveniente do comportamento corriqueiro de quem convive fora do jogo. Guildas voltadas para a profissionalização do jogo, como a Blood Fury, mencionada anteriormente (FALCÃO, 2015), e a Rise Above, ambas do Azralon, pouco mediam suas relações por algo diferente das dinâmicas de discriminação e prescrição. Para estas, o requisito é ser o melhor. Tal composição da Vipers, no caso, era responsável por algumas definições em sua estrutura: os grupos de raid apenas toleravam membros externos porque precisavam deles, e estes precisavam provar-se leais para chegarem a ser considerados como parte do núcleo da guilda. Além disso, alguns dos membros mais antigos da Vipers jogavam Warcraft desde sua versão vanilla, ou seja, sua primeira versão, datando de 2004. Há de se considerar que um grupo como este possui uma fidelidade a sua trajetória, especialmente porque no decorrer dos anos, seus integrantes enfrentaram uma série de testes de força (CALLON, 1991) que ameaçaram, por muitas vezes, a rede de se dissolver. Em sua idiossincrasia, o evento que havemos de descrever aqui se estabeleceu como um teste de força. Talvez não um que ameaçasse a rede em especial, mas um que ameaçou, sem dúvida, a sua essência - ou aquilo que os próprios jogadores acreditavam como sendo esta.

Dito isto, consideremos uma noite em especial, em meados de março de 2012. Após finalizar a raid inteira, derrotando Deathwing no fim, é comum que uma guilda se engaje no endgame em modo heroic. Os modos heroic são, como o próprio nome sugere, extremamente difíceis - tanto com relação a reflexos do jogador quanto com relação às prescrições internas do jogo, ao equipamento que um personagem precisa

A diferença entre guildas casuais e hardcore em Warcraft é sensível: guildas hardcore se reúnem quatro, cinco vezes por semana, para raidar durante quatro, cinco horas. Guildas casuais tendem a não se incomodar tanto com a progressão, raidando duas, três vezes por semana. A cobrança por performance também é modificada, assim como o escopo da relação entre os jogadores. 


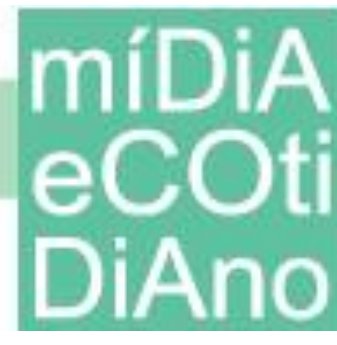

portar para poder ser efetivo em uma dessas lutas. Aqui, antes mesmo que nos aproximemos do ocorrido naquela noite, é possível que enxerguemos como estas cascatas de prescrição se dão no jogo: para fazer parte do grupo da Vipers, existe uma série de pré-requisitos: o primeiro deles, e talvez o mais importante, sendo o tempo de permanência na guilda.

A despeito desta prescrição não ser exatamente operacional, ela se justifica no suposto ethos do grupo, considerando que o núcleo deste era composto, quase que completamente, por amigos. Esta é uma prática relativamente comum entre guildas que raidam, pois aumenta a retenção dos jogadores no contexto, estimulando-os ase tornarem parte ativa da comunidade, não apenas entrar, participar de uma ou duas sessões de jogo e sair. Ainda assim, outras cascatas de recomendações se organizavam para que um jogador pudesse participar de uma raid junto à Vipers. À semelhança da discussão de Yee (2006) acerca de como jogadores de MMORPGs confundem seus horários de lazer com a dinâmica obrigatória do trabalho, pontualidade e frequência são outros dois problemas endereçados por prescrições especificamente relacionadas aos raid groups, mas como estes se afastam um pouco do universo dos não-humanos, deixemo-los um pouco de lado.

Retomando as prescrições de ordem operacional, duas podem ser tomadas como as mais centrais à prática: a primeira delas diz respeito a que tipo de equipamento pode ser utilizado em uma batalha como esta. A Blizzard, há muito, criou uma categorização para se manter no controle acerca de como o jogo escala. Esta categorização divide os itens em níveis $(i l v l)$, e considerando que cada personagem pode usar aproximadamente doze itens ao mesmo tempo, a combinação destes - cada um com seu ilvl particular oferece uma média que é o ilvl do personagem. Cada um desses itens pode, por sua vez, ser modificado - por encantamentos, gemas, reforjas. Esta medida serve para orientar os jogadores acerca de seu nível de preparo de acordo com uma luta específica.

A segunda diz respeito à interface: a Blizzard criou uma camada alterável que pode ser retrabalhada em uma linguagem de script chamada Lua $^{8}$. De posse desta ferramenta, usuários trabalham de forma colaborativa para garantir melhoramentos na

\footnotetext{
8 http://www.lua.org.
} 


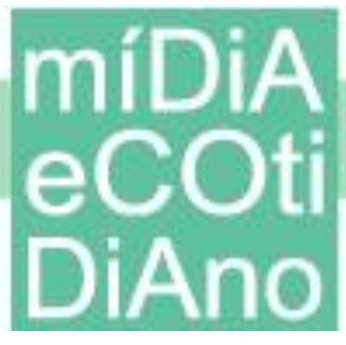

experiência de seus pares. As estratégias de customização são as mais variadas. Add-ons como o Recount, que possui o objetivo de quantificar as ações de um personagem em um combate, proporcionando assim o auto-monitoramento e um nível de vigilância acerca da performance de outros jogadores, ou o Power Auras, que possuía o intuito de sinalizar com veemência sempre que uma situação particular se instalava chegam, às vezes, a fazer tanto sucesso que são assimilados pelos desenvolvedores do jogo.

A Vipers possuía, então, duas regras básicas voltadas para estas duas especificidades. A primeira delas, um jogador tinha um limite mínimo de $i l v l$ - abaixo deste, ele não seria sequer considerado para integrar o time. A segunda se voltava para a interface: alguns add-ons eram de uso obrigatório, add-ons que facilitavam a comunicação entre o jogo e o jogador, atentando para detalhes de sua interface. Ambas as recomendações desencadeavam cascatas prescritivas. Para chegar a um certo ilvl, um jogador precisava, às vezes, jogar por dias a fio, torcendo para que itens específicos the cruzassem o caminho - ou ter muito gold, a moeda do MMORPG. De qualquer forma, para um ou para o outro, a chave está em quanto tempo se leva conectado em Warcraft.

Assim sendo, além destas regras básicas, uma terceira se instaurava: era necessário estudar. Não saber como uma luta se dá, não saber o que o boss vai fazer, a coreografia necessária a ser executada, pode fazer com que um jogador seja expulso de uma raid. Nos esportes como um todo, quando um jogador não conhece aspectos da tática de um time, ele pode ficar na reserva até aprendê-los - em Warcraft, o mesmo se dá. Guildas como a Blood Fury, são um caso à parte, nos quais um quis podia ser realizado a qualquer momento: os líderes escolhiam um membro qualquer e pediam-lhe que explicasse a luta, se este não soubesse, era banido não apenas da raid, mas da guilda, para que se soubesse que aquele era um locus de profissionalismo.

Observemos, então, de que forma podemos articular alguns não-humanos em específico para uma explicação como esta. A primeira prescrição - da guilda, lembremo-nos - diz respeito a uma atividade que conecta o mundo da narrativa para com o mundo simulado, das regras. Conseguir este equipamento necessário não é um feito apenas da alçada das regras, pois em Warcraft elas costumeiramente possuem explicações com base na história, nem é um feito da alçada da narrativa, naturalmente: 


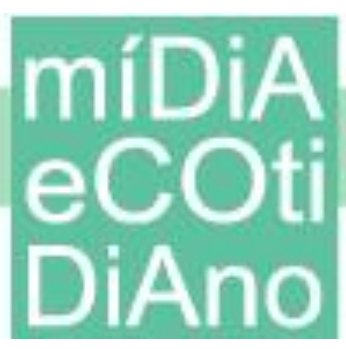

\section{PPGMC}

esta prescrição evoca uma interação híbrida para com ambos, que só pode ser compreendida a partir da ideia de Jørgensen (2013), de que o próprio mundo no qual o jogador "caminha", o mundo simulado do MMORPG, é uma segunda interface: "um puzzle em si mesmo, uma área de exploração que provê oportunidades de jogo muito específicas".

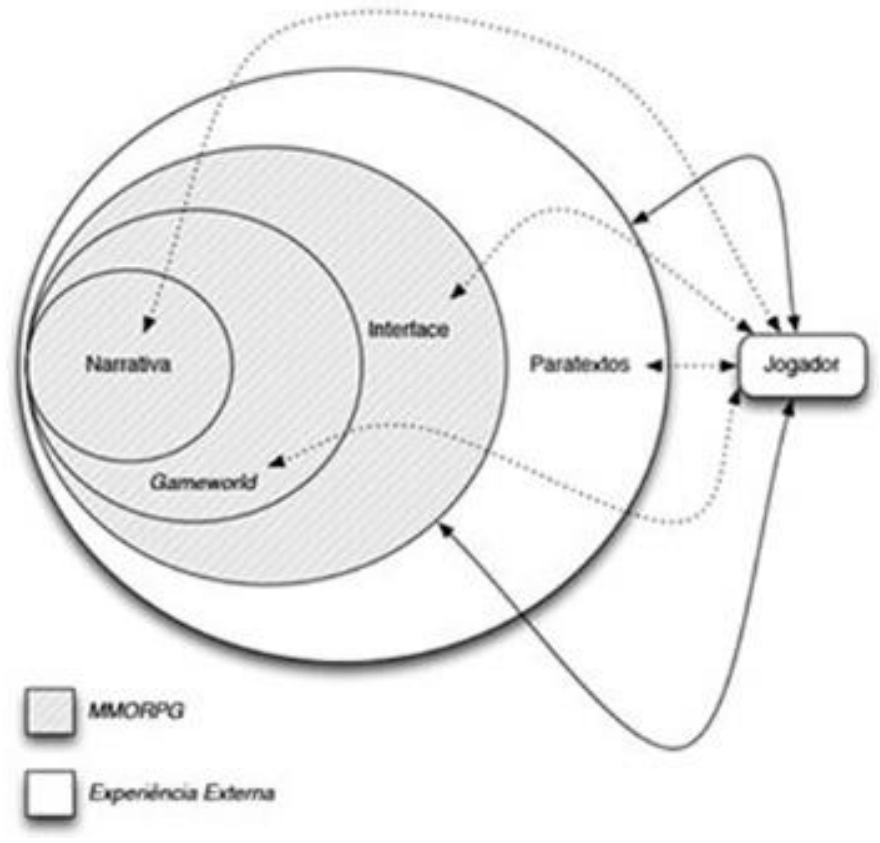

Figura 1: Camadas Relacionais de Prescrição em World of Warcraft.

Fonte: autoria própria.

Alguns fatores internos ao mundo, e que fazem convergir regras e ficção, certamente são parte vital o agenciamento de ações: estradas, estruturas, monstros e assim por diante. A jornada de um personagem até ele conseguir se equipar para raidar é imensa, e não vamos contemplá-la aqui - não há espaço. É importante perceber, contudo, que cascatas prescritivas são desencadeadas neste processo, e reconhecer que esta jornada possui uma dependência muito grande deste ator em específico, o (1) gameworld.

Em seguida, nos movamos rumo à (2) interface. Esta, por sua vez, se estabelece como área fronteiriça entre este gameworld e o jogador. Sem as ferramentas nela disposta, o jogador não consegue interagir para além do mais básico movimento, que é contemplado em sua contraparte material: teclado e mouse. Esta interface, em Warcraft, 


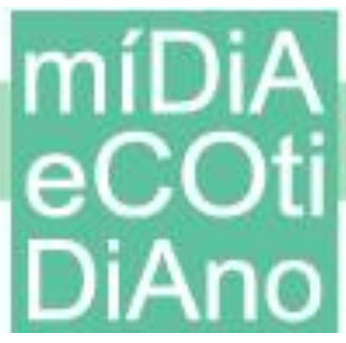

pode ser dita fruto da prática de hipermediação, como discutida por Bolter e Grusin (1999), através da qual a interface busca chamar atenção para o meio, e não se tornar transparente. Mais importante que isto, consideremos que os aspectos de customização desta - que vão desde funcionalidades, como as exigidas pela Vipers, por exemplo, até aspectos de customização que servem a propósitos de vaidade.

Aqui, a curva de aprendizado comum à prescrição se estabelece. Interfaces possuem uma sintaxe de ação, e a interação para com elas necessita de tempo para aprendizado. Este tempo é um fator importante, por exemplo, no desenvolvimento destas dinâmicas de discriminação. Os add-ons recomendados pela Vipers, contudo, não satisfazem esta ressalva, eles todos são voltados para dados da jogabilidade, e funcionam de forma passiva, não necessitando de novas perícias para seu uso.

De qualquer forma, o que merece destaque com relação à interface, neste sentido, é que quando em jogo - em especial em uma situação de tensão, como uma luta heroic, a atenção pode se voltar quase que completamente à interface. Os campos anteriores ainda podem ser considerados mediadores? Sim - sem dúvida. O gameworld ainda se mantém ali ativo, e é possível, sem dúvida, conjurá-lo de volta ao centro da ação, arrancá-lo da caixa-preta na qual ele se refugia - mas no caso de Ultraxion, isto não ocorre.

Os comandos de movimentação pelo mundo desaparecem, e a luta se dá, basicamente, numa combinação de botões que precisam ser apertados no tempo certo. A combinação precisa atingir (a) máxima performance do personagem e (b) exatidão na coreografia - e só assim este boss é derrotado.

Partamos para o último ponto, para que possamos discutir a organização da dada noite: (3) aprendizado: um dos pré-requisitos para que se chegue em uma luta como esta é, acima de tudo, saber o que fazer nela. Sim, é complexo: manter-se à frente do cronômetro é difícil, as variáveis são múltiplas e os componentes que desviam a atenção do jogador, fomentam os erros. Mas a estrutura da luta é facilmente acessível. Dezenas de vídeo-tutoriais são compartilhados todos os dias, com este intuito - e é precisamente a estes que nos referimos. O terceiro ponto, portanto, é o que diz respeito aos paratextos 


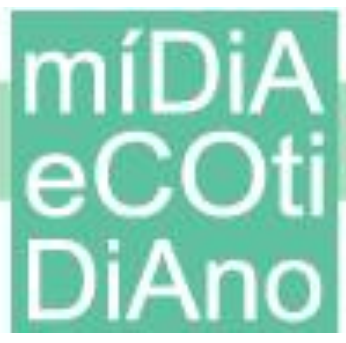

produzidos a partir do jogo, e que possuem usos múltiplos, apropriações variadas cujo potencial prescritivo foi discutido anteriormente (FALCÃO, 2015).

Por fim, a história é bem simples: o time se reuniu para tentar derrotar Ultraxion. Aquela era a terceira semana seguida na qual se repetia a reunião, sem grandes sinais de progressão. Naquela noite, em específico, o time desempenhou suas funções com precisão, poucos erros, e depois de algumas poucas tentativas - cada luta dura, em média, de cinco a oito minutos - chegou-se a um ponto no qual não havia erros, mas o boss não era derrotado. Ou os componentes variáveis da luta derrotavam o time faltava mana para os healers - ou excedia-se esse tempo médio, e o boss se enfurecia, eliminando todos os personagens e levando o esforço de volta à estaca zero.

A sutileza do problema pode não ser universal, então cabe um exemplo: se tentamos instalar um programa que demanda muita memória em um computador com pouca quantidade deste recurso, o que acontece? O programa não executa corretamente - e mesmo que o faça, ele o faz lentamente. Isto porque os cálculos do processador e da memória não são velozes o suficiente para fazer com que a entrega daquela operação seja ideal. A diferença deste problema para a situação da luta é que os cálculos são executados por cada jogador, por assim dizer. A conclusão, naquela noite, foi que "faltou DPS" - o que significa, basicamente, que o dano sendo infligido pelos jogadores não era o suficiente para derrotar aquele boss naquele espaço de tempo. Um problema matemático.

O detalhe que não foi pontuado é que o líder da guilda - um personagem da classe Paladin que atendia pela alcunha de Winona - estava abaixo do que era dele esperado. Não em termos de performance, ele era um dos mais antigos jogadores e estava acostumado a situações de risco. Seu equipamento, por sua vez, não era adequado à situação, dado o grupo. Nesta noite em específico, só havia um jogador na reserva, e seu equipamento era, coincidentemente, ideal para que o boss fosse derrotado. O impasse, então, se estabeleceu: o líder da guilda, que carregava consigo o próprio espírito desta, deveria dar o lugar a este outro jogador?

O impasse durou outras três tentativas - nas quais o grupo foi derrotado para os mesmos problemas - depois das quais Winona finalmente cedeu o lugar, por livre 


\section{míDiA \\ ecO DiAno}

vontade, ao outro jogador. Na primeira tentativa após a modificação, o boss foi derrotado e seus espólios divididos. O líder da guilda - e do grupo de raid - contudo, não pôde fazer parte do evento - não tendo acesso às suas recompensas ou ao prestígio de estar presente na primeira vez em que se deu a derrota do boss.

\section{Por uma Teoria das Agências}

O que extrair, portanto, de um evento como este?

Um pensamento de Bruno Latour, em especial, aqui se sobressai: "as agências só são visíveis quando observadas através de uma lente adequada" (2011). Uma afirmação como esta nos encaminha de pronto à noção de modo de existência (LATOUR, 2012), "um termo que eu utilizo para apontar para os vários tipos de agências que circulam pelo multiverso" (2011, p. 168).

O problema, então, é que quando nos debruçamos sobre uma organização qualquer, tentamos observar não que agências podem estar ali contidas, mas quais são as premissas daquela organização: para Latour (2011), ao fazer isso, o que empreendemos é um tipo de congelamento que responde apenas por uma esfera conceitual maximizada pela ação do que ele chama de clique duplo, um dos mecanismos de purificação da modernidade. Ao ignorar a possibilidade da versatilidade, da fuga ao script, um pesquisador achata seu objeto, fazendo dele não mais que um punhado de afirmações desconexas que não vão dar conta de uma descrição adequada de sua trajetória, quiçá de sua 'essência'. Em suma, o que executamos é a criação de uma grade na qual metaforicamente empurramos nossos objetos, fazendo com que eles ali se encaixem de pronto, sem que haja pensamento algum sobre o caso e sem que, em especial, ouçamos quem realmente pertence àquele contexto. "Logo que se fala sobre uma organização, perdem-se os modos específicos os quais apareceriam se participássemos de uma organização contando e recontando sua história” (LATOUR, 2011, p. 163).

Se em nenhum momento, ao discursar acerca da ideia de agência neste artigo, contrapusemos esta à noção de estrutura, aquela que lhe faz compor uma dicotomia para as ciências sociais, é porque em se tratando de um modo de existência 


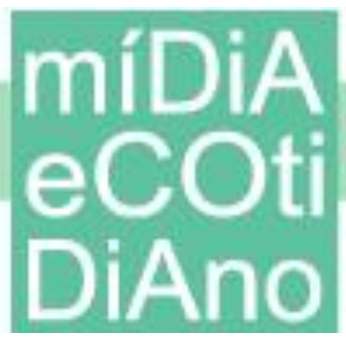

organizacional, esta dicotomia é, enfim, reconciliada. Para Latour (2011), decerto que cada organização possui um script, mas estes só são plenamente eficazes quando falamos sobre uma organização; nunca se participamos dela. Quando participamos de uma organização - e, para que fique claro, nosso intuito é articular esta noção com a guilda mencionada anteriormente - estamos sempre acima e abaixo dela, necessariamente submissos às suas regras mas jamais abrindo mão de apropriações deste script: "estamos simultaneamente sobre a história e abaixo dela - mas nunca completamente... e nunca exatamente no mesmo tempo e na mesma capacidade" (p. 164).

Em suma, é a repetição que garante a existência daquela essência - que é a consequência, e não a causa da duração. Se uma organização subsiste por anos e anos, isto se dá porque as duas faculdades se combinam em eterna reencenação. Eterna, até que se finde, naturalmente. Quando não houverem mais atores predispostos a assumirem certos papéis, a organização se esvai: "sua essência traída - ou seja, traduzida" (LATOUR, 2011, p. 168).

E quão semelhante ao universo do jogo - mais específico a esta problemática da Vipers - é esta discussão! A ideia não consiste em analisar quais são as regras de um grupo de raid, ou em analisar a movimentação dos jogadores quando numa situação como esta. A questão principal se encontra no fato de que estas regras existem, mas observá-las sem necessariamente entender que apropriações se dão não auxilia em nada o ofício do pesquisador. Mais que isso, a construção social observada, fora do cuidado para com o modo de existência assumido, muito provavelmente está errada.

Retornando, então, à situação, as regras da guilda, afinal, eram claras. Seus scripts - aqueles que constam em seu DNA metafórico, de acordo com o próprio Latour (2011) - estavam todos definidos e, é a impressão, estes são, afinal, aquilo que dá a uma organização a possibilidade de continuar sua trajetória, se desfazendo de seus hiatos: conquistando-os um a um. Sendo assim, como é possível que se quebrem as regras de tal forma? Como é possível que alguém menos preparado, menos pertencente, possa, de alguma forma, suprir aquele espaço que o líder do grupo construíra a tanto esforço? 
Nosso ponto, então, é chamar a atenção para as eventualidades do sistema. O aspecto material do gameworld, como foi especificado anteriormente. Como ignorar que, a despeito de existir uma linha narrativa ou um extremo corpo paratextual, a parcela operacional da experiência toma a frente, redefine seu programa de ação? Em um caso como este, a prescrição técnica é tão forte que a organização precisa sair de seu script, precisa tomar a agência em suas mãos e ignorar as premissas e o DNA, ou se arrisca a não conseguir sobreviver a um teste de força como este. Além disso, mais do que nos contemplar com uma certeza, este raciocínio nos contempla com uma questão: de que forma seria visível este problema em específico, a respeito da dinâmica das guildas voltadas para a prática de raiding em Warcraft, não considerássemos (1) a multiplicação destas camadas relacionais de prescrição, (2) um modo de existência peculiar a um grupo aparentemente tomado como trivial, por observadores incautos e (3) a própria prescrição sofrida pela necessidade do pesquisador mediante seu objeto de pesquisa.

Até então, seguimos discursando acerca não da ação narrativa, não acerca de personagens, tramas, enredos e clímaces, e sim de dimensões muito mais voltadas ao domínio do jogo, às conformações às regras, às apropriações dos jogadores. Consideramos não apenas o comportamento dos jogadores ingame - não apenas as ações que um jogador toma com relação ao mundo do jogo - mas todo o seu âmbito, em qualquer ambiente em que estejam, interagindo para com quaisquer outros atores.

O grande ponto que defendemos neste artigo é que, afinal, a teoria voltada para a questão da agência nos game studies pode não ser o suficiente. Talvez ela o seja, se nos debruçarmos sobre as questões da forma: se aderirmos às perspectivas da narratologia ou da ludologia. Trazendo para a tipologia que desenvolvemos acima, se ela se voltar para o gameworld - mas não se ela for além das fronteiras deste. Note-se, o esforço todo voltado para a questão da agência nos jogos eletrônicos é dedicado, segundo Murray (1997), para o que o personagem faz no jogo - nunca para sua interação para com o jogador. Nunca para as decisões do jogador ou, mesmo, para o que o leva a tecê-las.

O que buscamos, com este esforço, portanto, é que a questão da agência possa ser trabalhada não apenas nestes domínios específicos, mas que seu uso possa permitir que 


\section{míDiA \\ eco DiAno}

um pesquisador transite entre os contextos - aqueles que costumávamos nos referir como real e virtual, mas que hoje, sabemos, são perenemente imbricados - sem que este trânsito lhe custe epistemologicamente. Não é à toa que pesquisadores como MacCallum-Stewart e Parsler (2007) ou Krzywinska (2009) discursaram durante anos acerca de algo que eles consideravam ser uma agência ilusória: de posse de uma questão tão limitada, que tradução adequada do contexto pode se dar?

\section{Considerações Finais}

O problema aqui descrito, porta uma complexidade toda especial: ele não se subscreve apenas às dinâmicas do campo da comunicação, mas para que ele possa ser adequadamente estudado, precisa congregar esforços de outras searas, como o campo dos game studies e dos estudos em ciência e tecnologia (STS). Além disso, um problema que até então era de menor magnitude se sobressai como de importância epistemológica: que faculdades são necessárias a um pesquisador, para que ele consiga ter acesso aos códigos internos de uma subcultura, quando esta se relaciona tão intimamente com aspectos técnicos?

Nosso ponto, aqui, é afirmar que as dinâmicas prescritivas não apenas balizam as relações entre os jogadores no caso da formação do tecido social. Como adentrar um modo de existência e evocar as agências adequadas - humanas e não-humanas - se algumas das dinâmicas prescritivas não são satisfeitas - se o próprio pesquisador é alvo de discriminação?

Para além disso, uma construção analítica como as camadas relacionais de prescrição permite que possamos observar não apenas de que forma o jogador interage para com o jogo: sua combinação com modos de existência específicos pode iluminar facetas da interação entre homem e tecnologia que, ainda hoje, são obscuras. Consideremos, por exemplo, que mesmo nos game studies, estudos especificamente internos à prática de raiding profissional são escassos - e essa escassez tem a ver com o simples fato de que outras problemáticas são mais acessíveis, possuem um menor nível de discriminação. 
Buscamos, portanto, advogar uma teoria voltada para a questão da agência que dê conta de sua multiplicidade sem que caia em armadilhas purificadoras: observar a miríade de possibilidades em toda a rede é muito mais revelador, afinal, do que fazê-lo necessariamente dento ou fora do mundo virtual. Transcendamos, portanto, 1997.

Em específico, pelo fato de que esta fronteira, simplesmente, inexiste.

\section{Referências}

FALCÃO, Thiago. Uma Incursão sobre as Estruturas Comunicacionais em Mundos Virtuais: Estudo sobre a Mediação dos Diálogos pela Figura do Jogo. [Dissertação de Mestrado], Universidade Federal da Bahia, 2010

FALCÃO, Thiago. Camadas Relacionais de Prescrição: Rascunhos para uma Metodologia de Análise dos Jogos Eletrônicos. ESFERAS - Revista Interprogramas de Pós-graduação em Comunicação do Centro Oeste, v. 1, p. 145-157, 2013. 373-392, 2015.

Paratexto, Programas de Ação? Significação - Revista de Cultura Audiovisual, v. 42, p.

JØRGENSEN, Kristine. GWI: The Gameworld Interface. Proceedings of the Philosophy of Computer Games. Bergen: University of Bergen, 2013.

LATOUR, Bruno. The Enlightenment without the Critique: A Word on Michel Serres' Philosophy. In: A. Phillips Griffiths (Ed.). Contemporary French Philosophy. Cambridge: Cambridge University Press, 1988.

. Where are the Missing Masses? The Sociology of a Few Mundane Artifacts. In: Wiebe E. Bijker, John Law (Eds.). Shaping Technology / Building Society. Studies in Sociotechnical Change. Cambridge: The MIT Press, 1992.

Reassembling the Social. An Introduction to Actor-Network Theory. Oxford: Oxford University Press, 2005.

"What's the Story?". Organizing as a Mode of Existence. In: Jan-Hendrik Passoth, Birgit Peuker, Michael Schillmeier (Eds.). Agency without Actors? New Approaches to Collective Action. London: Routledge, 2011.

SAYES, Edwin Michael. Actor-Network Theory and Methodology: Just What Does it Mean to Say That Nonhumans Have Agency? Social Studies of Science. v. 44, n. 1, 2014.

STALDER, Felix. Actor-Network-Theory and Communication Networks: Toward Convergence. University of Toronto, 1997. Disponível em http://bit.ly/1jseEd0. Acesso em 03/12/2013.

TAYLOR, T. L. Raising the Stakes. E-Sports and the Profissionalization of Computer Gaming. Cambridge: The MIT Press, 2012. 